\title{
Historical Development of the Iowa Judiciary
}

\author{
By Charles F. Wennerstrum
}

A distinguished member of the bench and bar of Iowa, Judge Wennerstrum now practices law in Des Moines. He began his career in Chariton in 1915, was judge of the Second judicial district from 1930 through 1940, and was a member of the Iowa Supreme Court from 1941 through 1958. He was appointed one of the United States judges to the later Nurnberg war crimes trials. His history of the judiciary of Iowa is reprinted from Volume 40, Iowa Code Annotated, West Publishing Company, 1950, with slight revisions to bring the article up to the present.

A study of the development of the judicial system of Iowa necessitates a preliminary and limited consideration of the pertinent prior laws and historical facts which had an influence on the subsequent legislative enactments affecting the territory of Iowa and its laws, as well as the later constitutions and laws of the state. One of the early congressional enactments that pertains to what has been termed the Northwest Territory was the passage of the Ordinance of 1787 "for the government of the territory of the United States northwest of the river Ohio." This legislation, adopted July 13, 1787 by the Congress, provided for in the Articles of Confederation, authorized the formation within this territory of not less than three or more than five states. ${ }^{1}$ It was subsequently reapproved, confirmed and adapted to the constitution by the first Congress which functioned under that instrument. $^{2}$ The Ordinance provided for the appointment of a court, consisting of three judges, "any two of whom to form a court." It was given common law jurisdiction. As a prerequisite to serving, the judges were required to be residents of the district and possess a "freehold estate in five hundred acres of land, while in the exercise of their office." The commission of the judges appointed was to continue during good behavior.

1 Article 5, Ordinance of 1787.

21 United States Statutes at Large, p. 50. 
The area which comprised the Northwest Territory was subsequently divided from time to time and resulted in the formation of the state of Ohio and thereafter the territories of Indiana, Michigan, Illinois, and Wisconsin. This territory northwest of the Ohio was successively subject to the laws of the several territorial legislatures as they came into being and to the jurisdiction of the respective territorial courts provided for in the legislation concerning each new territory.

What is now the state of Iowa was part of French Louisiana until after the French and Indian War. Its judicial administration was under the jurisdiction of the Superior Council at New Orleans. This Council administered the law as provided for by the Custom of Paris. ${ }^{3}$ In districts far removed from New Orleans, there were local judges under appointment. Their decisions were subject to appeal to and review by the Superior Council. The Council of State at Versailles, however, exercised a right of review. After the French and Indian War when Louisiana was ceded to Spain in 1762 a code was adopted and the appellate jurisdiction, where the amount was in excess of ninety thousand maravides, was transferred to Havana. ${ }^{4}$ However, the transfer of authority did not actually become effective until 1769 .

By the secret treaty of San Ildefonso Napoleon in 1800 reacquired Louisiana for France and in April, 1803 it was transferred to the United States."

By a congressional act, approved March 26, 1804, it was provided that the part of Louisana north of latitude $33^{\circ}$ (the southern boundary of the present state of Arkansas) was to be administered under the governor and judges of the Indiana Territory. They had power to enact laws and create inferior courts. ${ }^{6}$

On July 4, 1805, all of the area now comprising Iowa came under the jurisdiction of the Territory of Louisiana when

3 Vol. 22, Reports of Louisiana Bar Association, pp. 25-38.

4 Ibid, pp. 48-56.

5 "Historical Review of the Judicial System of Minnesota," Loring, 27 Minnesota Statutes Annotated, p. 57; Foster $v$ Neilson, 2 Peters, 254-299.

62 United States Statutes at Large, pp. 283-287. 
it was established with a form of government similar to that provided for in the Ordinance of 1787.7

On June 4, 1812, which was approximately two months after the state of Louisiana was admitted into the Union, what remained of the Territory of Louisiana was organized as the Territory of Missouri. ${ }^{8}$ In 1821 the state of Missouri was admitted to the Union. From 1821 until 1834 the Territory of Missouri north and west of the state of Missouri was not effectively administered by any governmental unit. In 1834 that part of the area east of the Missouri and White Earth rivers was attached to the Territory of Michigan. ${ }^{9}$ The Territory of Michigan had theretofore only extended to the Mississippi river.

The Territory of Wisconsin was organized in 1836. The area now comprising the state of Iowa was included within its boundaries. Through legislation approved by Congress on April 20, 1836 the Organic Law of Wisconsin was incorporated into the laws of the United States. It was therein provided $^{10}$ that the judicial power of the territory should be vested in a supreme court, district courts, probate courts and in justices of the peace. It was also provided that the Supreme Court of the Territory of Wisconsin should consist of a chief justice and two associate justices, any two of whom should constitute a quorum. They were to continue to hold office during good behavior. The jurisdiction of the several courts provided for in the Organic Law of Wisconsin was to be limited by law, although it was therein provided that the justices of the peace should not have jurisdiction of any controversy affecting the title or boundaries of land, or where the debt or sum claimed exceeded fifty dollars. It was also therein provided that the supreme and district courts should possess chancery as well as common law jurisdiction.

The inhabitants of the Wisconsin Territory, under the law passed relative to it, were given the right to enjoy all the rights and privileges granted to the people under the terms

7 Ibid, p. 331.

8 Ibid, p. 743.

94 United States Statutes at Large, p. 701.

105 United States Statutes at Large, p. 10. 
of the Ordinance of 1787 and all the rights secured to the Territory of Michigan and its inhabitants. ${ }^{11}$

\section{TERRITORIAL IOWA}

A congressional act was passed and approved on June 12, 1838 which provided that from and after July 3,1838 , “. . . all that part of the Territory of Wisconsin which lies west of the Mississippi river, and west of a line drawn due north from the head waters or sources of the Mississippi to the Territorial line, shall, for the purposes of temporary government, be and constitute a separate Territorial Government by the name of Iowa." ${ }^{2}$ What is now Minnesota west of the Mississippi and two-thirds of North and South Dakota became a part of Fayette County, Iowa. ${ }^{13}$

The legislative assembly of the Territory of Iowa consisted of a council (senate) and house of representatives. The judicial power of the territory was vested in a supreme court, district courts, probate courts and in justices of the peace. ${ }^{14}$ The supreme court consisted of a chief justice and two associate justices, any two of whom should constitute a quorum. They were to hold court at the seat of the territorial government and it was provided that the justices were to hold office for a term of four years. This congressional enactment further provided that the territory should be divided into three judicial districts and a district court was to be held in each of the three districts by one of the judges of the supreme court. Consequently the territorial supreme court would review the cases that one of their number had tried. It was further provided that the jurisdiction of the several courts, both appellate

11 Sections 15 and 16 of the Organic Law of Wisconsin provided that all suits and process, proceedings, indictments and informations undetermined on July 3, 1836 in certain counties including ". . . Iowa, Dubuque, Milwaukee, and Des Moines" should be transferred and be determined in the district courts established which may include these counties. It was further provided that all undisposed of cases in the Supreme Court of Michigan which shall have been or may be removed from the counties of Brown and Iowa should be transferred to the Supreme Court of the Territory of Wisconsin for final determination.

12 Organic Law of Iowa, 5 United States Statutes at Large, p. 235, approved by Congress June 12, 1838.

13 Act of Wisconsin Territorial Legislature, December 21, 1837. Loring, op. cit., pp. 53, 59.

145 United States Statutes at Large, p. 235. 
and original, as well as that of the probate courts and justices of the peace would be limited by law. ${ }^{15}$ Justices of the peace were specifically denied jurisdiction of controversies affecting title or boundaries of land and where the debt or sum claimed exceeded fifty dollars. The supreme and district courts of the territory were, under this congressional legislation, given chancery as well as common law jurisdiction. The salary of the justices of the territorial supreme court was fixed at fifteen hundred dollars annually.

Under the provisions of the legislation heretofore commented upon all rights, privileges and immunities granted to the inhabitants of Wisconsin were granted to the inhabitants of the territory of Iowa and the existing laws of the territory of Wisconsin were extended over the Iowa territory if not incompatible with the provision of the legislation pertaining to the territory of Iowa. It was provided, however, that the applicable laws of Wisconsin might be altered, modified, or repealed "by the Governor and Legislative Assembly of the said territory of Iowa."16 The justices of the peace, constables, sheriffs, and all other executive and judicial officers in that portion of the territory of Wisconsin which became a part of the territory of Iowa were to continue in their respective offices until others should be appointed by the territorial government of Iowa, but it was provided that no such officer should continue in office longer than one year after the formation of the territory of Iowa. In a congressional enactment, approved March 3, 1839, it was provided that the legislative assembly of the territory be authorized to provide for the election or appointment of sheriffs, judges of probate, justices of the peace and county surveyors. ${ }^{17}$

As increase in population came to the area that is now Iowa the inhabitants developed a frontier type of justice of their own. The immigrants were zealous in their contention for land claims. In order to give stability to their respective

15 Section 7 of the Organic Law of Iowa stated that "The governor shall nominate and by and with the advice and consent of the legislative council, shall appoint all judicial officers, justices of the peace, sheriffs, and all militia officers ..."

16 Ibid, par. 12.

17 Ibid, p. 357, enacted March 3, 1839. 
claims these immigrants from time to time and in various portions of the state formed claim associations for the purpose of protecting their property rights from those who came in later and sought to pre-empt their holdings. These associations would thus protect the original claimants until the land was offered for sale and under some circumstances would so develop sentiment and prevent them from having outsiders over-bid them. These claim associations were extra legal but nevertheless effective. ${ }^{18}$

One of the early criminal cases which was tried in Iowa did not have the benefit of an official stamp nor was it presided over by any judge appointed or named by any legal authority. As far as is known this was the first murder trial in the Iowa country. In 1834 Patrick O'Connor was accused of killing one George O'Keaf. These two men had built a cabin some two miles south of Dubuque where they were operating a mine. O'Keaf had gone to Dubuque for provisions and on returning was refused immediate entrance to the cabin and being angered by the refusal of admittance he broke down the door. O'Connor shot and killed his partner during this disturbance. A trial by those living nearby resulted. He was found guilty and subsequently hanged. ${ }^{19}$

18 George F. Robeson, "Justice in Early Iowa," Palimpsest, Vol 5 (March, 1924), pp. 102-113.

19 Jacob A. Swisher, "The Judiciary of the Territory of Iowa," Iowa Journal of History and Politics, Vol. 20 (April, 1922), pp. 224-226. A short eyewitness description by Eliphaelt Price in the Dubuque Herald was printed in the Annals of Iowa, First Series, State Historical Society of Iowa, No. XII (October, 1865), p. 538.

This case of frontier justice which was tried on May 20, 1834 was held in the open air in the town of Dubuque. O'Connor was tried without the benefit of formal court proceedings by a group of Dubuque citizens. Inquiry was made of him as to who he wished for counsel and he is quoted as saying, "Faith, and I'll tind to my own business." A Captain Bates of Galena, Illinois, who was present there that day was finally selected by O'Connor to be his counsel. On being formally charged with the crime of murder and being asked as to whether he pleaded guilty or not guilty, O'Connor replied, "I'll not deny that I shot him but ye have no laws in the country and cannot try me." This contention was the basis of his defense and was the subject of considerable controversy for some time. After a deliberation of an hour's length the jury found him guilty. An application was made to the governor of Missouri to pardon O'Connor, but he replied that he had no jurisdiction over the country and suggested that an application be made to the president of the United States. This was done but President Jackson replied, after consideration of the application for a pardon, that the laws of the United States had not been extended over the newly acquired purchase and 


\section{The Territorial Courts}

The governor of the Territory of Wisconsin, Henry Dodge, in his first annual message to the Wisconsin Territorial Legislative Assembly on October 26, 1836, recommended to that body that it take early action "in defining the jurisdiction and powers of the several courts of this territory, dividing the territory into judicial districts, and prescribing the time and places of holding the proper courts."20

The territorial legislature of Wisconsin thereafter on November 15th passed an act which provided that the counties of Dubuque and Des Moines should constitute the Second Judicial District. The counties named were much larger in size than the counties now so named and they were subsequently divided. An act of the Wisconsin territorial legislature, approved December 7, 1836, resulted in the division of Des Moines County into seven new counties one of which retained the name of Des Moines. The other six counties created by this act were: Lee, Van Buren, Henry, Louisa, "Musquitine" (Muscatine), and Cook. This last named county is now a part of Johnson, Muscatine and Scott counties.

that he had no authority to act in the matter. On June 20,1834 O'Connor was hanged in compliance with the verdict of the jury which had found "that the said Patrick O'Connor is guilty of murder in the first degree, and ought to be, and is by us sentenced to be hung by the neck until he is dead; which sentence shall take effect on Tuesday the 20th day of June, 1834, at one o'clock P.M."

John C. Parish, "White Beans For Hanging," Palimpsest, Vol. 1 (July, $1920)$, pp. 9-28, relates an example of frontier justice at Bellevue in Jackson County. It occurred in 1837. Criminal activities of some of the residents had developed to the extent that a criminal charge was filed against a large group of citizens. The criminal proceedings in the court were not carried out and the citizens of the community determined that they could and should take more effective action. There were some thirteen men taken into custody by the group. They then voted to determine what should be the punishment inflicted on the men they held in custody. This was done by two men passing among the group. One of them carried a box containing red and white beans and the other one carried an empty box to receive the votes. It was related that the man with the beans, as he approached each individual in the group called out, "White beans for hanging, colored beans for whipping." There were eighty men who voted and upon a counting of the beans it was determined that by a margin of three the colored beans for whipping were in the majority. The whipping resulted and the thirteen men were then placed on boats on the Mississippi, supplied with three days rations and made to promise never to return.

20 Benjamin F. Shambaugh, ed., Messages and Proclamations of the Governors of Iowa, Iowa State Historical Society, 1903, Vol. I, p. 3. 
By an act of the Wisconsin territorial legislature on December 21,1837 , the county of Dubuque was divided and from it was formed fourteen new counties. These were: Dubuque, Clayton, Jackson, Benton, Linn, Jones, Clinton, Johnson, Scott, Delaware, Buchanan, Cedar, Fayette and Keokuk. ${ }^{21}$

With the passage of the congressional act, approved June 12 , 1838, creating the territory of Iowa, President Martin Van Buren appointed Robert Lucas of Ohio as governor and William B. Conway of Pennsylvania as secretary. The judges of the supreme court who were appointed were: Charles Mason of Burlington, chief justice, Joseph Williams of Pennsylvania and Thomas S. Wilson of Dubuque as associate justices. The nature and extent of the activities of this court varied from time to time as the territorial legislature enacted legislation relative to their duties.

The men who comprised this first territorial court had high qualifications and their influence on the development of the state has been recognized. On November 21, 1838, the House of Representatives of the territorial legislature adopted the following resolution: "Resolved, by the Council and House of Representatives of the Territory of Iowa, that the judges of the Supreme Court be requested to furnish this Legislative Assembly, during its present session, with such bills as will in their opinion form a proper code of jurisprudence for Iowa, and regulate the practice of the courts thereof." This resolution was approved by the council (senate) and the law became effective. ${ }^{22}$ Several bills were submitted to the legislature during the 1838-1839 session by members of the court.

The first case which is found in the first Iowa report, Morris, p. 1, is "In the Matter of Ralph (a colored man), on habeas corpus." This case was tried before Judge Wilson of the supreme court in the district court of Dubuque. The opinion of the supreme court was written by Chief Justice Mason and it was therein held that where a slave becomes a permanent resident of a free state with the consent of his master

21 See map with Frank Harmon Garver, "History of the Establishment of Counties in Iowa," Iowa Journal of History and Politics, Vol. 6 (July, 1908), p. 443.

22 Journal of the Council, 1838-1839, p. 41. 
he cannot be regarded as a fugitive slave. ${ }^{23}$ This opinion is in direct conflict with the later decision of the supreme court of the United States in the Dred Scott case.

A very interesting comment on the three first supreme court judges is found in Recollections and Sketches by Stiles, pp. 19-52. As has been previously stated the supreme court justices were assigned as judges of certain district courts. Judge Mason had the lower district, Judge Williams the middle district and Judge Wilson had the northern district. This was when there were only three district courts. The experiences in these early courts were novel and interesting. ${ }^{24}$

\section{Constitutions of the State of Iowa}

The judicial system of Iowa naturally has as its basis the constitution of the state. The first constitution of Iowa was adopted August 3, 1846. Incidents relative to its adoption, as well as the Constitution of 1857 , have been admirably commented upon in an article entitled "History of Constitutions of Iowa" by John Eli Briggs, Professor of Political Science, State University of Iowa, 1 Iowa Code Annotated pp. 1-36. The second constitution was adopted at a constitutional convention held in Iowa City on March 5, 1857. It was in effect a revision of the original Constitution of 1846.

In the Constitution of 1846 it was provided that the judicial

23 Judge John F. Dillon, a former member of the Iowa Supreme Court, said in a paper delivered before the Iowa Association of New York: "By that decision Iowa became the first free child of the "Missouri Compromise.' And when, in contemplating the State of Iowa today in its maturity, we look back through the intervening years to the early days when Ralph's case was decided, we are for many reasons filled with pride."

24 Judge Thomas S. Wilson recalled in Edward H. Stiles, Recollections and Sketches, The Homestead Publishing Co., 1916, p. 51: "The first term of court in Jackson County was held by me in an unoccupied building belonging to Mr. Heffley, a grocer. A hogshead of molasses which was in the room was rolled against the side wall, with the end upward. Judge Grant was trying his first case in that county and the following ludicrous incident illustrates one of his well-known peculiarities. While addressing the jury the high-pitched, shrill and piercing tones of his voice, for which he was distinguished, reached far and near the ears of the loungers on the outside, who thinking there must certainly be a row on hand rushed pell-mell for and into the court room. The bailiff, a short man, mounted on top of the hogshead to restore order, but while in the act of doing so at the top of his voice, the head of the cask gave way and he went down chin-deep into the molasses. The effect of this on the court proceedings can be imagined better than described." 
power of the state should be vested in a supreme court, district courts, and such other inferior courts as the general assembly might from time to time establish. It was further provided that the supreme court should consist of a chief justice and two associate justices, two of whom should constitute a quorum. It was also provided that the judges of the supreme court should be elected by a joint vote of both branches of the general assembly; that the term of office of the judges of the supreme court should be for six years; that they should be ineligible for any other office during the term for which they were elected; that the supreme court should have appellate jurisdiction only in all cases in chancery, and should constitute a court for the correction of errors at law. A further provision was that the district court should consist of a judge elected by the qualified voters of the district in which he resided, that the term of office of the district judge should be five years, and that such judge should be ineligible for any other office during the term for which he was elected. It was further provided that the district court should be a court of law and equity, having jurisdiction in all civil and criminal matters arising in their respective districts.

The Constitution of 1857, which with limited amendments constitutes the present constitutional authority for the state of Iowa, followed very largely the provisions of the Constitution of 1846. One important change is noted in that in section 3 of Article $\mathrm{V}$ of the Constitution of 1857 it is provided that judges of the supreme court should be elected by the qualified electors of the state rather than by both branches of the general assembly, as was provided for in the Constitution of 1846. Under the Constitution of 1857 the salary of the judges of the supreme court was fixed at $\$ 2000$ per annum and that of each district judge at $\$ 1600$ per annum. It further provided that after the year 1860 the several judges should receive such compensation as the general assembly might prescribe, it being further provided, however, that such compensation should not be increased or diminished during the term for which the judges were elected. One interesting provision in the Constitution of 1846, as well as in the Constitution of 1857 , is that no divorce should be granted by the General 
Assembly of Iowa. This constitutional prohibition now seems strange to a student of Iowa procedure but by reference to the acts of the territorial legislatures from 1840 to 1846 it will be observed that several divorces were granted at each legislative session. ${ }^{25}$

A further change in the Constitution of 1857 from that of the Constitution of 1846 was the provision that the district court should be a court of law and equity and should have distinct and separate jurisdictions.

During the early period of the history of the state and prior to the Constitution of 1846 , when there were innumerable squatters seeking land holdings in the Iowa territory these immigrants at times adopted constitutions as a basis for the preservation of their rights and the development of peaceful communities. In some of these constitutions provision was made for the hearing of complaints by a committee which was authorized to decide the controversies according to justice and equity. It was a provision of one of these constitutions that any party "considering injustice had been done shall have the right to appeal to the Grand Committee (nine members), together with the President, who shall investigate the same, and shall give their decision in writing, from which there shall be no appeal." ${ }^{26}$ These early squatter constitutions give evidence of the development of a desire for a fundamental law among the pioneers. The "Miners Compact" of June 17, 1830 constituted an agreement among the miners in or near Dubuque relative to their holdings and has been referred to as the first constitution in Iowa. ${ }^{27}$ Undoubtedly many of the matters incorporated in the written constitutions of Iowa are the result of ideas expressed by the early settlers in these squatter constitutions.

25 A territorial legislative divorce act in Chapter IX, Laws of the Territory of Iowa, 1840, Reprinted in 1912 , p. 6 , is typical of other acts of that character: "That the marriage contract heretofore existing between Elizabeth Jones and Berry Jones, be and the same is hereby dissolved; and that hereafter she be called and known by the name of Elizabeth Massengill. Presented to the Executive, December 16, 1840."

26 Benjamin F. Shambaugh, The Constitutions of Iowa, Iowa State Historical Society, Iowa City, 1934, p. 45.

27 John C. Parish, "The Langworthys of Early Dubuque," Iowa Journal of History and Politics, Vol. 8 (July, 1910), p. 317. 


\section{CoDES}

Governor Robert Lucas on November 12, 1838 called to the attention of the Territorial Legislature of Iowa the advisability of a committee being named “. . . to digest and prepare a complete code of laws during the recess of the Legislature and to report them for consideration at the ensuing session." 28 This suggestion was not followed but a resolution was adopted asking the judges of the supreme court to furnish the legislature with suggested bills which would make possible a code of jurisprudence for Iowa. Many of the important laws passed at the first session of the Territorial Legislature were written and submitted by Charles Mason, Chief Justice of the Territorial Supreme Court. The laws passed by this first Legislative Assembly were subsequently published and although they constituted a mere compilation of the session laws this was in reality the first "code" in Iowa. It has been referred to as "The Old Blue Book." 29 It contained the statute laws of the territory for the legislative session 1838-39.

By reason of succeeding legislative enactments a revision was necessary and in 1842 the legislature named a joint committee to carry out this work and in 1843 this revision, which has been called, "The Blue Book," was published.

The extra session of the first General Assembly of the state of Iowa enacted a law, approved January 25, 1848, appointing Charles Mason of Des Moines County, William G. Woodward of Muscatine County and Stephen Hempstead of Dubuque County a committee “. . . to draft, revise and prepare a code of laws for the state of Iowa." 0 The Code of 1851 was thereafter enacted on February 5, 1851.

The Seventh General Assembly (1858) passed a joint resolution appointing Wm. Smith of Linn County, W. T. Barker of Dubuque County and Charles Ben Darwin of Des Moines County ". . . commissioners to draft and report to the Ju-

28 Clifford Powell, "History of the Codes of Iowa Law," Iowa Journal of History and Politics, Vol. 9 (October, 1911), pp. 493-498.

29 Dan E. Clark, "Codification of Statute Law in Iowa," Iowa Applied History Series, State Historical Society of Iowa, Iowa City, 1916, Vol. III, pp. 402, 403.

30 Code of 1851 , p. 470. 
diciary committee of the two houses a Code of Civil and Criminal procedure; and also to report such changes as may seem necessary to harmonize existing laws and adapt them to the new constitution; (1857) and said Commissioners to Revise and Codify the General Laws of the State so far as practicable ..." ${ }^{31}$ They reported to the Eighth General Assembly and the Revision of 1860 was thereafter adopted and published.

The Code of 1873 was the result of an act passed by the Thirteenth General Assembly, approved April 7, 1870, for the appointment of commissioners to revise the existing statutes of the state. Following the publication of the Code of 1873 there was no revision or codification of the laws of Iowa for twenty-four years but in 1880 there was issued by Emlin McClain an annotated compilation including the Code of 1873 and subsequent statutes. Likewise in the year 1880 there was a similar compilation prepared by Judge Wm. E. Miller. These compilations were known as McClain's and Miller's codes. Further publications by McClain include McClain's Supplement, 1882-1884; McClain's Annotated Statutes, 1884; McClain's Annotated Code, 1888 and McClain's Supplement, 1888-1892. Other publications by Miller were Miller's Revised and Annotated Code, 1883; Miller's Revised and Annotated Code, 1884; Miller's Annotated Code, 1886; Miller's Revised and Annotated Code, 1888 and Miller's Revised and Annotated Code, 1888-1890. Other privately published works relative to Iowa codes and annotations include: T'emplin's Compendium of Repeals and Amendments, 1871; Overton's Annotated Code of Civil Procedure for lowa and Wisconsin, 1875; Templin's Compendium of Repeals and Amendments, 1878; Stacy's Code of Civil Procedure, 1878 and Davis' Criminal Code, 1879.32 The McClain and Miller codes, privately published, were officially recognized by the General Assembly and were generally accepted throughout the state.

The matter of recodification of the laws of Iowa received the attention of the 24th General Assembly (1892) and the

31 Code of 1860, Preface, iii-vi; See Chapter 40, Acts and Resolutions of the 7th General Assembly, 1858, printed in 1913, pp. 39, 40.

32 Clifford Powell, "History of the Codes of Iowa," Iowa Journal of History and Politics, Vol. 12 (January, 1914), pp. 17-33. 
25th General Assembly (1894). The General Assembly in 1894 passed a law appointing a commission of five persons to “. . . carefully revise and codify the law . . . and make any and all alterations necessary to improve, systematize, harmonize and make the laws clear and intelligible." ${ }^{33}$ This commission consisted of Emlin McClain appointed by the Senate, John Y. Stone and Charles Baker, appointed by the House, and $\mathbf{H}$. S. Winslow and H. F. Dale, appointed by the Supreme Court. This commission submitted its report to the 26th General Assembly (1896) but due to the pressure of other business and the desire to give further attention to the report it was found that the revised code could not be adopted at that time. The revision, which was approved by the extra session of the 26th General Assembly (January 19, 1897-July 2, 1897), is known as the Code of 1897.

Thereafter there was published the code supplement of 1902. A cumulative supplement was published in 1907. There was also published a cumulative supplement to the code in 1913. A supplemental supplement (1.915) was later published, which was subsequently bound with the 1913 cumulative supplement.

Following the use of the Code of 1897 and the supplements thereto for approximately 22 years the 38 th General Assembly (1919) provided for a new revision of the laws. ${ }^{34}$ Under the provisions of this act, three commissioners were provided for, one of whom was to be the Supreme Court reporter. The commissioners named were James W. Trewin of Cedar Rapids, J. C. Mabry of Albia and U. G. Whitney, the reporter of the Supreme Court. The code commissioners prepared and published as directed a compilation of the laws known as the Compiled Code of Iowa, 1919. This compiled code was generally intended for the use of the General Assembly. There were only 2500 copies printed. The commissioners also submitted some 253 bills which amended, revised and codified certain sections and reported to the 38th General Assembly on February 1, 1920. The 39th General Assembly (1921) di-

33 Acts and Resolutions of the 25th General Assembly, 1894, ch. 115, sec. 4; "The Iowa Codes," Emlin McClain, 1 Iowa Law Bulletin, pp. 3-25, 26.

34 Acts and Resolutions of the 38th General Assembly, 1919, ch. 50. 
rected that its acts of a general and permanent nature be published in the form of a supplement to the compiled code. Provision was also made for an extra session at which time it was contemplated that the matter of code revision would receive consideration. Governor William L. Harding was not disposed to call an extra session and the matter of the code revision was further delayed until the meeting of the 40th General Assembly (1923). This assembly did not give much attention to the matter pertaining to code revision and Governor N. E. Kendall called an extra session of the 40th General Assembly to convene on April 18, 1923, the day following the adjournment of the regular session. After the convening of this extra session the General Assembly recessed until December 4, 1923, at which time consideration was given to the code commissioner's bills. By reason of the delay in the enactment of the code revision bills as contemplated there was published a Supplement to the Compiled Code, 1923. The Code of 1924 was the result of the work of the code commissioners and the legislative attention to code revision, although only about one-half of the existing statutes were revised. The remainder of the Code of 1924 was a compilation. The extra session of the 40th General Assembly which had convened on December 4, 1923 completed its work on April 26,1924 . In view of the fact that the code could not be completed "ninety days after the adjournment" of this extra session, as provided for in the Constitution relative to acts passed at a special session, the General Assembly recessed until July 22, 1924 and finally adjourned on July 30, 1924 with the laws enacted taking effect ninety days thereafter. ${ }^{35}$ Under the provisions of the Code of 1924 it was provided that the editor should edit and compile the code after each even-numbered session of the General Assembly. ${ }^{36}$ Thereafter there has been published the Codes of 1927, 1931, 1935, 1939. During World War II this statute was changed and provision was made for a new code to be published after each odd-numbered session p. 1.

${ }^{35}$ See "The Iowa Code of 1924," O. K. Patton, 10 Iowa Law Review,

36 Code of 1924, par. 156(2); "Continuous Code Revision in Iowa" O. K. Patton, 13 Iowa Law Review, pp. 1-46. 
of the legislature with the result that the publication of the next code was postponed until 1946. ${ }^{37}$

In each of these several codes, to which reference has been made, there have been set out legislative enactments relative to the judicial system of Iowa. It is impossible within the limitations of this study to detail all the changes which have been made concerning the administration of the courts of Iowa. Reference to and comments relative to these several courts which have served and are now serving the State of Iowa will be hereinafter commented upon. In these several codes, particularly the early codes, will be found many matters of interest which under present conditions seem extremely odd. ${ }^{38}$

\section{County Judges-County Courts}

By an act of the extra session of the 6th Legislative Assembly of Michigan, which was held in September, 1834, the Iowa portion of the Michigan territory was divided into two counties by the running of a line due west of the lower line of Rock Island. The portion north of this line was named "Du Buque" County and that south of it was Des Moines County. The first county court holding sessions in Iowa sat at Burlington in April, 1835. ${ }^{39}$ The Executive Journals of

37 Acts and Resolutions of the 50th General Assembly, 1944, ch. 56, par. 2; Code of 1958, par. 14.15.

38 Section 2388, Code of 1851 provided: "Every human being of suffcient capacity to understand the obligation of an oath is a competent witness in all cases both civil and criminal except as herein otherwise declared. But an indian, a negro, a mulatto or black person shall not be allowed to give testimony in any cause wherein a white person is a party." That portion of the section which related to an indian, a negro, a mulatto, or a black person, was repealed in 1856-57, Acts and Resolutions of the 6th General Assembly, 1913 reprint of the session laws of Iowa, pp. 325, 326.

Section 2390 , Code of 1851, provided that "a person who has a direct, certain legal interest in the suit is not a competent witness unless called on for that purpose by the opposite party as hereinafter provided." This provision is not incorporated in the Revision of 1860 and subsequent codes. See Acts and Resolutions of the 8th General Assembly, 1860, ch. 90, \& 1, making parties in interest competent witnesses, 1913 reprint.

Section 8, Chapter 29, Extra Session of the Territorial Laws of Iowa, 1840, which was part of a statute repealing the laws of Michigan and Wisconsin then applicable in Iowa (as provided for in the Act of Congress of June 12, 1838, ch. 96, 5 U.S. Stat. at Large 235) states: "None of the statutes of Great Britain shall be considered as law in this territory." However, for a judicial consideration of this last referred to statute see O'Ferrell $v$. Simplot, 4 Iowa 381, 401.

39 "Iowa's Supreme Court," AnNals of Iowa, Third Series, Vol. 26 (July, 1944), p. 4. 
Michigan Governors disclose ${ }^{40}$ that during the period the Iowa country was under the jurisdiction of Michigan appointment of judges for certain counties in what was later Iowa was made. On December 26, 1834 William Morgan was appointed judge for Des Moines County and Lorin Wheeler for Dubuque County. On June 20, 1835 John King was appointed judge for Dubuque County and on March 31, 1836 Isaac Leffler (as spelled in Executive Journal) was appointed for Des Moines County. As has been previously set out the area now comprising Iowa was in turn transferred to the territory of Wisconsin and thereafter to the territory of Iowa.

On February 15, 1843 the territorial legislature authorized the organizing of a board of county commissioners to transact county business. ${ }^{41}$ Their duties were virtually the same as those now exercised by the present board of supervisors.

Chapter 15 of the Code of 1851 provided that county judges should be elected at the first election held in August after this statute had been in force thirty days, and that if such election did not take place in 1851 county judges elected in 1852 should hold office for a term of three years, and a new election should take place at the August election in the year 1855 and each four years thereafter.

From a perusal of the chapter heretofore referred to the county judge had much the same authority as the present county auditor. He had authority to provide for the erection and repair of the court house and county jail and other necessary buildings for the use of the county. ${ }^{42}$

The county court had jurisdiction of the probate of wills, the administration of the estates of deceased persons and of the guardianship of minors and insane persons. It was a further provision of this legislation that the business pending in either the probate court or the court of the board of com-

40 Correspondence with the Michigan State Library.

41 James O. Crosby, "The County Judge System," AnNals of Iowa, Third Series, Vol. 10 (April, 1911), pp. 42, 43.

42 In the case of ex rel. Brooks $v$. Napier, County Judge, 1858, 7 Iowa 425, an action concerning the erection of a court house in Polk County, it was held that the county judge may enter into contracts for the erection of necessary public buildings, binding upon the county thereby, and without first submitting the question to the voters of the county. See also Hull \& Argalls $v$. The County of Marshall, 12 Iowa 142. 
missioners in any county when the statute relative to the county court took effect should conform to this statute. However, it was provided that no matter would be void if it did not conform to the county court legislation, provided in its administration it was conducted legally according to the preexisting statutes. ${ }^{43}$

Early supreme court decisions relative to the county court held that it was of limited jurisdiction and had no authority to adjudicate titles to land, ${ }^{44}$ that the decisions of the county judge were in legal effect the decisions of the county court, ${ }^{45}$ that the county judge had two distinct characters, that of being the general agent of the county and the other as judge. ${ }^{46}$ In a case involving a question concerning the respective jurisdictions of the district court and the county court, acting as a probate court, it was held that the jurisdiction of the county court in matters pertaining to the settlement of estates was not exclusive and that the district court had jurisdiction as an equity tribunal to consider a petition of creditors asking that the administrator sell necessary real estate for the payment of debts. ${ }^{47}$

Very extensive powers given the county judge under the statute included the laying out of towns, the incorporation of villages and towns, and the licensing of ferries, with the authority to forbid competition a mile each way from a licensed ferry. The judge was authorized to grant licenses for the erection of toll bridges where the expenses of such a bridge were greater than could be met by the revenues of the county, and in conjunction with the county judge of an adjoining county might establish toll bridges over line streams. Authority in connection with many other matters, too numerous to mention within the limitations of this article, was given the county judge. In many cases the temptations for easy wealth were too many for certain county judges. It has been said that "the county judge took quick rank as the most corrupt

$43 \mathrm{Ch} .15$, sec. 140, Code of 1851, p. 28.

44 Hall v. McMahon, 1854, 4 G. Greene 376.

45 Lee County v Nelson, 1854, 4 G. Greene, 348.

46 Campbell $v$ County of Polk, 1856, 3 Iowa 467.

47 Waples $v$ Marsh, 1866, 19 Iowa 381. 
official of the state . .." and “. . . many great fortunes were gleaned from the office during the single term of three years." 48 It should be stated that the characteristics heretofore set forth did not apply to all county judges.

Under the provisions of the Code of 1851 it was provided: "The people of this state will hereafter take no share in the profits of retailing intoxicating liquors, but the traffic in those commodities as articles of merchandise is not prohibited." The law was provided with enforcement provisions and thereafter the legislature placed the administration of the liquor traffic in the hands of the county judge. ${ }^{49}$ The administration of the sale of intoxicating liquors was a further temptation to the county judges and undoubtedly some of them profited by reason of their position. ${ }^{50}$

Because of the criticism directed toward the county judge system, and some particular judges, most of their authority was thereafter taken from them by the legislature, except that pertaining to being a probate judge. The administrative duties relative to the county were transferred to a board of supervisors. $^{\overline{1} 1}$ The General Assembly in April, 1868 established circuit courts and there was transferred to them what remained of the county judges' jurisdiction. ${ }^{52}$ The office of

48 A. D. Bicknell, "The Early Courts of Iowa," Iowa Historical Record, Vol. 17 (April, 1901), pp. 262-277.

49 Acts and Resolutions of the 5th General Assembly, 1854-55, Ch. 45, par. 3, reads in part: "The county judge of any county, on the first Monday of May annually, shall appoint some suitable person or persons, not more than two in number, residents of said county, but not both residents of the same township, to act as agent or agents of such county, for the purchase of intoxicating liquor, and for the sale thereof within such county, for medicinal, mechanical and sacramental purposes only. And the said county judge may remove such agent at his pleasure and appoint another in his stead, at such time after such removal as shall be convenient. Every such agent shall hold his office one year unless sooner removed. He shall sell such liquor only in one place, to be designated in the written certificate to be given him by the county judge, and no two agents shall be allowed to sell such liquor in the same township. He shall, in the purchase and in the sale of such liquor, conform to such rules and regulations as shall be prescribed by said county judge, not inconsistent with the provisions of this act. . . . He shall sell such liquor at such prices as shall be prescribed by the county judge, not, however, to exceed twenty-five per cent upon the cost thereof ...."

50 Bicknell, supra.

51 Title 3, ch. 22, art. 11, Code of 1860, pp. 48-53.

52 Acts and Resolutions of the 12th General Assembly, 1868, ch. 86, par. 3, p. 113. 
county judge was abolished by Ch. 160, 12th G.A., approved April 7, 1868, and until the election of a county auditor it was provided that the county judge should be ex-officio the county auditor.

\section{Circuit Courts}

Following the Civil War and the business development thereafter, the adoption of a Homestead Bill, and the extension of railroads into Iowa, a great immigration into this state developed. The population increased from 674,913 in 1860 to $1,191,792$ in 1870 .

As the result of this influx of immigrants and the resulting development within the state the work of the supreme court, as well as the district courts, became congested and the submission of cases and their final disposition were delayed. At that time there were only twelve judicial districts. In order to remedy the condition in the district courts the legislature in 1868 sought to relieve this situation by the creation of a circuit court. Its jurisdiction, with limited exceptions, was similar to that of the district court. No question was ever raised during the period this court was in existence as to the constitutionality of the act creating it, but it should be kept in mind that under Article 5, Section 1 of the Constitution of 1857 it is provided that: "The judicial power shall be vested in a supreme court, district courts, and such other courts, inferior to the supreme court, as the General Assembly may, from time to time establish." However, under Section 10 of Art. V there was a limitation placed as to the manner and number of judges increased. ${ }^{53}$

The circuit court came into existence by reason of an act of the 12th G. A., approved April 3, 1868. This legislation provided that circuit courts should be established throughout the

53 Article V, sec. 10, Constitution of 1857: "The State shall be divided into eleven Judicial Districts; and after the year Eighteen hundred and sixty, the General Assembly may re-organize the Judicial Districts and increase or diminish the number of Districts, or the number of Judges of the said Court, and may increase the number of Judges of the Supreme Court; but such increase or diminution shall not be more than one District, or one Judge of either Court, at any one session; and no reorganization of the districts, or diminution of the number of Judges, shall have the effect of removing a Judge from office. Such reorganization of the districts, or any change in the boundaries thereof, or increase or diminution of the number of Judges, shall take place every four years thereafter, if necessary, and at no other time." 
state and each judicial district should be divided into two circuits and that the judges elected should hold office for a term of four years. It was further provided that each of the judges should hold at least four terms of court in each county of a circuit in each year, that this court should have original and exclusive jurisdiction in matters relating to probate of wills, the appointment and supervision of executors, administrators, guardians and minors, and settlement of decedents' estates. It was also provided that this court should have jurisdiction concurrent with the district court in all civil actions at law, foreclosure of mortgages, contracts for the sale of real estate, and was further authorized to direct and determine equitable issues arising in law actions pending in the circuit court. It was also given jurisdiction in all partition actions, actions for the assignment of dower and in all appeal proceedings for the assessment of damages on the establishment or location of highways, railroads and other public improvements, or the taking of private property for public use.

The statute to which reference has been made did not give the circuit court authority to empanel a grand jury, but did permit the trial of misdemeanors which had been filed in the district court and the defendant was held in custody, subject to the approval of the district court and the consent of the defendant. It was further provided that any case pending either in the district court or the circuit court might, with the consent of the parties, be transferred to the other court within the same county. It was also provided that each circuit judge should have the same power in regard to injunctions, writs, and orders, as was possessed by district judges. They were also authorized to solemnize marriages.

One interesting feature of this act was that it provided for what might be termed an intermediate court of appeals.

This appeal court was referred to as a general term and it was provided that in each judicial district there should be held not less than two nor more than four general terms each year at which the court should consist of a district judge and two circuit judges within that district. The district judge within the respective district was the presiding judge. It was further provided that appeals to this court should be taken in 
the same manner and under the same rules as appeals taken from the district court to the supreme court, except that no appeal to the general term should be allowed after the expiration of three months from the entry of the judgment or order appealed from. Other provisions of the act pertained to the manner of administration.

The general term or appeal session which was provided for in the circuit court act did not prove practical. It was cumbersome and expensive and was repealed by the next legislature.

The circuit court was in existence for eighteen years and it is said that it handled approximately 100,000 cases ${ }^{54}$ It was abolished by a legislative act, effective January 1, 1887. Following the abolishment of the circuit court one of the judges brought an action against the auditor of state for his salary claiming that although the circuit court was abolished the office of circuit judge had not been. On appeal to the supreme court the contentions of the circuit judge were not sustained. ${ }^{55}$

\section{Supreme Court}

In the consideration of other phases of the development of the judicial system of the state comment has been made concerning the supreme court during the early period of the history of the state. As the work of the court has increased the number of judges has likewise been increased. In order effectively to administer the work of the court during such periods the statute provides for the sitting of the court in two divisions. Provision for an increase in the number of judges has occurred during the periods in the state's history when there has been economic development or instability.

Early statutory enactments provided for argument terms in cities other than at the seat of gevernment. Such terms were first held in Davenport, ${ }^{56}$ later also in Dubuque ${ }^{57}$ and Council

54 Gordon L. Elliott, "Circuit Courts of Iowa," AnNals of IowA, Third Series, Vol. 23 (October, 1941), pp. 126-137.

55 Crozier $v$ Lyons, Auditor of State, 1887, 72 Iowa 401.

56 Acts and Resolutions of the 7th General Assembly, 1858, ch. 82, par. 1, approved March 20, 1858.

57 Acts and Resolutions of the 12th General Assembly, 1868, ch. 27, par. 1, approved March 10, 1868. 
Bluffs. ${ }^{58}$ This plan inaugurated in 1858 was discontinued in 1886.59

During the years from $1913^{60}$ through $1918^{61}$ the election of supreme court, district court, and superior court judges was on a nonpartisan basis. This manner of selecting judges apparently did not bring about the desired results and was changed back to the political party system. The nominees of the respective parties are now selected at a party judicial convention held separately from the general political convention.

Even though at times the supreme court has had a number of undisposed cases, a condition which has not existed for some time, there has been no effort made to establish an intermediate appeal court, with the exception of the general terms of the circuit courts.

Through December, 1960 there have been seventy-nine different individuals elected or appointed to the supreme court of Iowa ${ }^{62}$ which number includes one unseated in an election contest. ${ }^{63}$

\section{District Courts}

As previously stated the Organic Law of Wisconsin was for a time applicable in the area which now comprises the state of Iowa. In it provision was made for the establishment of a district court. The section of the Organic Law of Wisconsin relative to the judicial power being vested in certain courts was incorporated with limited changes into the Organic Law of Iowa. It was provided therein that the supreme court

58 Acts and Resolutions of the 14th General Assembly, 1873, ch. 89, par. 1, approved April 10, 1872.

59 Laws relative to argument terms were repealed by the 21 st General Assembly, effective April 1, 1886.

60 Acts and Resolutions of the 35th General Assembly, 1913, ch. 104, p. 91, approved April 11, 1913.

61 Acts and Resolutions of the 38th General Assembly, 1919, ch. 63, par. 1, p. 75, approved March 17, 1919.

62 Biographical sketches of all Supreme Court, Territorial and State judges to April, 1945, prepared by Frederick F. Faville, Wayne Faupel and Viola Bartlett appear in ANNALs OF IowA, Vol. 26 (1944-1945), pp. 6-22, 139-154, 205-228, 235-236, 275-290, 311.

${ }^{63}$ State of Iowa ex rel E. C. Halback, County Attorney, appellee, v George Claussen, appellee, Hubert Utterback, appellant, 1933, 216 Iowa 1079 . 
judges after their appointment, should reside in the districts which would be assigned to them. The provision as to residence was not incorporated into the Organic Law of Wisconsin. In the Territorial Code (statute laws) of Iowa (18381839) legislation is set out relative to the holding of terms of the district court in the several counties of the territory and the manner in which these courts should be administered. A statute was adopted by the territorial legislature in 1839 by which the district courts were given exclusive jurisdiction of all matters in chancery and this statute sets out in detail the manner of the administration of the chancery power of the district court. In the Constitution of 1846 provision was made for a district court. ${ }^{64}$ The constitution also provided that the district court "shall consist of a judge" and that it should be a court of law and equity having jurisdiction in all civil and criminal matters arising in their respective districts. In the Code of 1851 the manner of the administration of district courts was set out.

In the developing era of the state it was quite apparent that the members of the legislature were desirous of correcting any imperfections in the existing laws. Legislation was enacted to make this possible. ${ }^{65}$

64 Constitution of 1846, Article V, par. 1; Code of 1851, pp. 552, 553.

65 Section 1588, Code of 1851, p. 235, reads: "Each of the judges of the supreme and district courts shall report to the legislature at each regular session thereof, all omissions, descrepancies, or other evident imperfections of the law, which have fallen under his observation." Sections of the Revision of 1860 , pp. 469,470 pertain to the same subject.

Section 2675: "In 1860, and every sixth year thereafter, there shall be appointed by the governor, by and with the consent of the senate, three commissioners of legal inquiry, who shall hold their office for six years, and any vacancy, by resignation or otherwise, may be filled by the governor, subject to the approval of the senate then, or next to be in session."

Section 2676: "Each of the judges of the supreme and district court shall report to the chairman of such commission, as fast as the same shall fall under his observation, any omission, discrepancy, or other evident imperfection of the law of civil or criminal procedure."

Section 2677: "Such commission may report to the legislature at each regular session, such amendments in civil or criminal procedure, as they may deem advisable, in order to carry out the intent and general spirit of the system of practice herewith adopted."

Section 2678: "They shall not, nor shall any of them receive, either directly or indirectly, any compensation for their services."

These were repealed by H.F. 3, Acts and Resolutions of the 14th General Assembly, 1873, Adjourned Session. 
Part Three of the Code of 1851 was devoted to courts and their civil procedure. Part Three of the Revision of 1860 likewise was devoted to courts and civil practice. In the section of the Revision of 1860 pertaining to courts and procedure there is incorporated in a footnote a lengthy report of the code revision commissioners wherein much historical information is given relative to the basis of much of the procedure adopted for the courts of Iowa. The limitation of this article permits only its mention here, but it merits the study of interested persons.

With the discontinuance of the circuit court and the turning over to the district court of all trials, other than in justice courts, and administrative matters attendant to the district court, its importance and influence gradually developed. Under statutory enactments the district court has been given much authority in making appointments and to hear certain matters on appeal, the details of which are too numerous to mention.

Statutory enactments have increased the number of district judges and also authorized increases in salary. As of 1961 there are twenty-one judicial districts and seventy-five district judges.

\section{Probate Courts}

Probate courts have been mentioned in previous comments concerning the historical development of the state and its judicial system. Although the term probate court or probate procedure was not mentioned in the Ordinance of 1787 , yet it is of interest to note that the manner of descent of property and the transfer of property by wills was deemed of such importance that it was incorporated into section two of that document. The Organic Law of Wisconsin provided for the establishment of a probate court, as did the Organic Law of Iowa. Probate courts are not mentioned in the Constitution of 1846 or in the Constitution of 1857.

The first Territorial Code (statute laws) of Iowa (18381839) provided for the establishment of "Courts of Probate" in each of the organized counties. This court had supervision of such matters as are now handled by our present probate court as part of the district court. 
Thereafter, as stated probate matters were under the jurisdiction of the county court or county judge, the circuit court, and the district court. A study of the various ways in which probate matters have been handled during territorial times and after statehood gives one a broad conception of our developing judicial system.

\section{Conciliation and Arbitration}

The Iowa Code provides for the manner of settlement of controversies by conciliation. The statute provides that the judges of the district court for their district, the judges for the superior court for their court, and the judges of the municipal court for their court may adopt and enforce rules relative to the matter of the settlement of controversies by conciliation. It is also provided that in such proceedings the parties involved shall not be represented by counsel, except by the consent of the conciliator who may be a judge or a person appointed. It is a further statutory provision that in districts in which rules for conciliation are adopted and the conciliator appointed, no person may maintain an action for the recovery of a disputed claim for $\$ 100$ or less unless he alleges and proves by a certificate of the conciliator that he has made a good faith effort to settle the controversy. This last referred to provision is not applicable in suits aided by attachment or to enforce a lien, or for replevin, or upon written contracts when due, or when the petition states that the defendant is about to change his residence from the county or where either party to the controversy is a nonresident of the county.

Legislation for the settlement of controversies by conciliation was passed by the 40th G.A. (1923) and first incorporated in the Code of 1924.

Commencing with the territorial statutes and later in the Code of 1851 and subsequent codes provision has been made for the submission of all controversies which might be the subject of civil action to one or more arbitrators for arbitration.

The settlement of controversies under the statutory provisions for conciliation have not been used extensively. They are probably used to a limited extent in some of the municipal 
courts of the state. The provisions relative to arbitration have apparently been more generally used as is evidenced by the number of cases cited in the annotations.

\section{Additional Courts}

Under a provision of the constitution which vested the judicial power of the state in a supreme court, district courts, "and such other courts, inferior to the supreme court as the General Assembly may, from time to time, establish," legislation has been enacted which provides for courts wherein three, and in one case five, judges are authorized to act. The Code of 1851 provided that in a contest of an election involving the office of secretary, treasurer, or auditor of state, judge of the district court, or superintendent of public instruction, the trial of such contested state election should be held before a court consisting of three judges of either the supreme or district court. ${ }^{66}$ The Code of 1958 , by virtue of prior amendments, now provides that in an election contest case involving state officers, except that of governor and lieutenant governor, the contest court shall consist of three district judges selected by the chief justice of the supreme court. In a case where the chief justice is a party to the contest the governor shall select the district court judges.

The statute also provides for three judge courts to hear cases for the condemnation of public utilities by a municipality and disbarment charges against attorneys. ${ }^{67}$

In the case of a contested election for presidential electors the court to hear such a case shall consist of the chief justice of the supreme court who shall be the presiding judge of the court and four judges of the district court to be selected by the supreme court. ${ }^{68}$ It is a provision of the statute that the judgment of this contest court shall constitute a final determination of the title to the office, and a certificate shall be issued to the successful party as an elector. It would thus appear that there can be no appeal from the decision of this court.

It is interesting to note that Article V, section 1 of the Constitution of 1846 provides that "The judicial power shall be

66 Code of 1851, pars. 368, 369.

67 Code of 1958, secs. 397.21, 610.30 .

68 Code of 1958 , sec. 60.1 . 
vested in a supreme court, district court, and such inferior courts as the General Assembly may from time to time establish," while Article V, section 1 of the Constitution of 1857 provides that "The judicial power shall be vested in a supreme court, district court, and such other courts, inferior to the supreme court, as the General Assembly, may from time to time, establish."69

\section{JUVENILE COURTS}

Juvenile courts are an integral part of the district courts of Iowa, unless administered by judges of a superior or municipal court upon designation by the judges of the district court. ${ }^{70}$

The adoption of the juvenile court law on April 6, 1904, effective as of July 4th of that year, was the result of a movement sponsored by Cora Bussey Hillis of Des Moines and other interested persons. ${ }^{71}$ This court and its administration has justified its adoption as a part of our judicial system. It is an evidence of a tendency to administer the many juvenile problems that are brought before this court in a forward looking manner. A study has been made of and an article written relative to the attitude of Iowa judges toward the juvenile court and its administration. This study indicates that most of the judges have a cooperative attitude in connection with these problems. $^{\mathbf{7 2}}$

\section{Superior CourT}

Initial legislation relative to the establishment of superior courts was adopted by the 16th General Assembly (1876). ${ }^{73}$

The Iowa statute provides that in cities with a population of four thousand or over a superior court may be established. This court has concurrent jurisdiction with the district court in all civil matters, except in probate matters and actions for

${ }^{69}$ See Hetherington $v$ Bissel et al,, and Baker $v$ Bissell, 1859, 10 Iowa $145,148$.

70 Code of 1958, secs. 231.1-231.3.

71 Hazel Hillis, "Securing the Juvenile Court Law in Iowa," AnNaLs of IowA, Third Series, Vol. XXIII (January, 1942), p. 161.

72 "Iowa Judges and the Juvenile Court," Davis, 34 Iowa Law Review, 634 .

${ }^{73}$ See "Classification of Cities for Superior Court Purposes," Wayne G. Cook, 12 Iowa Law Review, pp. 138-162. 
divorce, alimony and separate maintenance. It has exclusive original jurisdiction to try and determine all actions, civil and criminal, for the violation of city ordinances, and all jurisdiction conferred on police courts, and concurrent jurisdiction with justices of the peace. A superior court judge, by designation of the judges of the district court, may act as a judge of the juvenile court.

As of 1960 there is only one functioning superior court in Iowa, which is at Keokuk. This court has been in existence in Keokuk since April 10, 1883. In Oelwein a superior court was authorized at the election held November 4, 1902. The first term of this court opened on February 16, 1903. The court continued to actively function until May 1, 1943. No judge is now holding office. An election to abolish the court has not been held. In Perry a superior court was established at an election held March 25, 1907. This court continued to operate until December 31, 1920. Since that time no election for the selection of a judge has been held nor has there been an election to abolish the court. Other cities where there have been superior courts, with the approximate date of establishment and discontinuance are: Cedar Rapids, April 2, 1877January 1, 1954; Council Bluffs, March 19, 1882-April 15, 1924; Shenandoah, March 19, 1882-March 31, 1933; Creston, June 13, 1887-January 27, 1894; Grinnell, November 3, 1908April 1, 1933; and Iowa Falls, November 6, 1928-March 31, $1930 . .^{74}$

\section{Municipal Courts}

A municipal court may be established in any city having a population of five thousand or more. ${ }^{75}$ It is a court of record, which records shall be kept in substantially the same form and manner as the district court. It has concurrent jurisdiction with the district court in all civil matters where the amount in controversy does not exceed one thousand dollars, except in probate matters, actions for divorce and alimony and separate maintenance, and actions affecting the title to real estate. The judges of the district court may designate a municipal court judge to act as judge of the juvenile court in cases

74 Correspondence with court and city officials.

75 Code of 1946, sec. 602.1. 
arising in any city in which any such court is organized and in cases arising in any part of any county convenient thereto.

In criminal matters the court shall exercise jurisdiction conferred on the district court, on justice of the peace courts and on police courts for the prosecution of misdemeanors. A municipal court also has jurisdiction coextensive with the territorial limits of the county, except as limited by statute. Appeals may be taken to the supreme court and district court in the manner provided by statute. Municipal courts may be abolished by the majority vote of the electors voting at an election where the proposition of abolishment of the court is submitted. ${ }^{76}$

Initial legislation pertaining to the establishment of municipal courts was adopted by the 36th General Assembly (1915). As of 1960 eleven Iowa cities have municipal courts. These cities with the approximate dates of the establishment of the court in the respective cities are: Des Moines, April 1, 1916; Clinton, April 2, 1918; Waterloo, May 1, 1918; Marshalltown, November 24, 1919; Council Bluffs, April 15, 1924; Ames, November 1, 1928; Sioux City, March 28, 1932; Burlington, November 1, 1948; Cedar Rapids, November 3, 1953; Ottumwa, January 1, 1960; Cedar Falls, January 2, 1960. ${ }^{77}$

\section{Mayor and Police Courts}

By virtue of statutory provisions it is provided that in all cities of the first class where there is no municipal or superior court there shall be a police court which shall have the jurisdiction in criminal actions of a justice of the peace court, and mayor's court. This court is a court of record. ${ }^{78}$ In cities having a superior, municipal, or police court, such court shall have exclusive jurisdiction of all actions or prosecutions for violation of city ordinances.

In other cities and towns, the mayor shall have exclusive jurisdiction of all actions or prosecutions for violations of city or town ordinances. The mayor's court shall also have, in criminal matters, the jurisdiction of a justice of the peace, co-extensive with the county, and in civil cases, the jurisdiction

76 Ibid, sec. 602.51 .

77 Correspondence with court officials.

78 Code of 1958, sec. 367.1. 
within the city or town that a justice of the peace has within the township.

Initial statutory provisions for both police courts and mayor's courts are first noted in the Revision of 1860.

\section{Justices of the Peace}

The fact that justice of the peace courts were particularly referred to in early legislation concerning our courts indicate their importance in our early judicial system. During the pioneer stage of the development of the state when travel was limited, justice of the peace courts provided reasonably prompt administration of justice in causes of limited jurisdiction. As the mode and manner of travel have changed so has the importance of this court. However, it still has a place in our judicial system. There have been suggestions made that the present justice of the peace courts should be abolished. The justice of the peace courts undoubtedly have their faults but with the right of appeal to the district court always present they no doubt serve a worthwhile purpose, at least, in the handling of traffic violations in communities where there are no municipal courts.

\section{Rules of Civil Procedure}

Under the provisions of Chapter 311, Acts and Resolutions of the 49th General Assembly, (1941), the Supreme Court of Iowa has prescribed rules of pleading, practice and procedure in actions of a civil nature in the courts of this state. This legislation and the resulting Rules were for the purpose of "simplifying the same (practice and procedure) and of promoting the speedy determination of litigation upon its merits." 79

The present Rules of Civil Procedure are the result of a movement that developed in recent years. The adoption of the new Rules has been generally accepted and approved by the bench and bar of the state. The legislation that made these Rules possible is further evidence that the judges and lawyers of the state, as well as the state legislature, are desirous of making our legal procedure function effectively and promptly. The fact that the legislation provides for the change of the Rules by the supreme court, except that they shall be reported

79 Letter of transmittal, Supreme Court Report to the 50th General Assembly, p. iv; Code of 1946, p. 2137. 
to the legislature, makes for reasonably prompt changes as circumstances develop.

Proposed Constitutional Amendment

The General Assembly in 1959 passed a constitutional amendment to change the method of selection and tenure of judges in Iowa. If approved in identical form during the current session of the legislature, it will be submitted to the voters in a special election in 1962. This amendment provides that the Governor appoint justices of the Supreme Court and district judges from a list of nominees selected by a nonpartisan representative commission, with the voters having the opportunity to remove an unsatisfactory judge in a noncompetitive election.

\section{Conclusion}

The courts of record in Iowa, with the possible exception of the early county courts, have been so administered as to merit the confidence of the people living within the state. The judges who have administered our courts, with few exceptions, have been persons of high character and of high intellectual and legal attainment. Consequently the courts of this state have generally been recognized as a division of our government in which great confidence has been placed. This confidence will be continued and merited if the individuals. who administer our courts will be ever mindful that they are custodians of a high trust, a trust that has developed throughout the years-a trust which, if well administered, will make for the preservation of our form of government.

\section{History of Cigarette Smoking}

Cigarette smoking is compartively a recent habit in the United States, being introduced in the early seventies. There were very few cigarettes manufactured until 1875 . . . . It originated among the lower classes of Russia, Poland and France, and for a long time was confined to the same classes in this country. Today it is recognized by students of social problems to be one of the most dangerous, degrading and demoralizing evils, and demands the early attention of our legislators toward its arrest.-Eighth Biennial Report of the Board of Health of the State of Iowa, 1895. 
Copyright of Annals of Iowa is the property of State of Iowa, by \& through the State Historical Society of Iowa and its content may not be copied or emailed to multiple sites or posted to a listserv without the copyright holder's express written permission. However, users may print, download, or email articles for individual use. 